
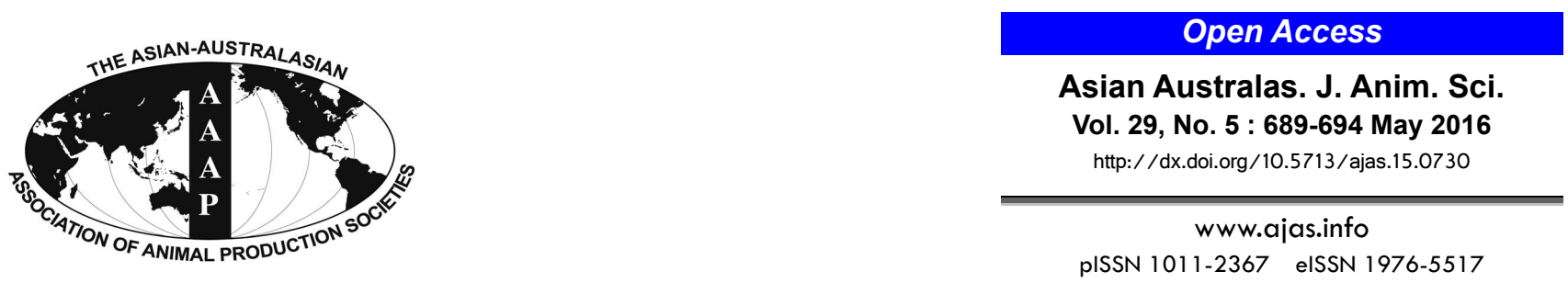

\title{
Effect of L- or DL-methionine Supplementation on Nitrogen Retention, Serum Amino Acid Concentrations and Blood Metabolites Profile in Starter Pigs
}

\author{
Q. Y. Tian, Z. K. Zeng, Y. X. Zhang, S. F. Long, and X. S. Piao* \\ State Key Laboratory of Animal Nutrition, Ministry of Agriculture Feed Industry Centre, \\ China Agricultural University, Beijing 100193, China
}

\begin{abstract}
The objective of the current study was to evaluate the effect of supplementation of either L-methionine (L-Met) or DLmethionine (DL-Met) to diets of starter pigs on nitrogen $(\mathrm{N})$ balance, metabolism, and serum amino acid profile. Eighteen crossbred (Duroc $\times$ Landrace $\times$ Yorkshire) barrows weighing $15.45 \pm 0.88 \mathrm{~kg}$ were randomly allotted to 1 of 3 diets with 6 pigs per treatment. The diets included a basal diet (Met-deficient diet) containing $0.24 \%$ standardized ileal digestibility Met with all other essential nutrients meeting the pig's requirements. The other two diets were produced by supplementing the basal diet with $0.12 \%$ DL-Met or L-Met. The experiment lasted for 18 days, consisting of a 13-day adaptation period to the diets followed by a 5-day experimental period. Pigs were fed ad libitum and free access to water throughout the experiment. Results showed that the supplementation of either L-Met or DL-Met improved $\mathrm{N}$ retention, and serum methionine concentration, and decreased $\mathrm{N}$ excretion compared with basal diet $(\mathrm{p}<0.01)$. The $\mathrm{N}$ retention of pigs fed diets supplemented with the same inclusion levels of DL-Met or L-Met were not different ( $p>0.05$ ). In conclusion, on equimolar basis DL-Met and L-Met are equally bioavailable as Met sources for starter pigs. (Key Words: Amino Acids Profile, Methionine, Pigs, Nitrogen Balance)
\end{abstract}

\section{INTRODUCTION}

Methionine (Met) is one of the most important essential amino acids (AA) in livestock nutrition. It is a limiting amino acid in complex pig diets containing spray dried blood products or dried whey (Cromwell, 2004). Apart from its nutritional function, Met is also important for the metabolism and gut health of animals. Through transmethylation Met can be converted to Sadenosylmethionine, a primary methyl donor that methylates compounds to form such products as creatine and phosphatidylcholine (Finkelstein, 1990; MartínVenegas et al., 2006). Methionine can be converted to cysteine, a precursor of glutathione, and taurine. These molecules may regulate intestinal epithelial oxidative status, and may contribute to intestinal mucosal integrity and gut

\footnotetext{
* Corresponding Author: X. S. Piao. Tel: +86-10-62733588, Fax:+86-10-62733688, E-mail: piaoxsh@mafic.ac.cn

Submitted Sept. 3, 2015; Revised Nov. 27, 2015; Accepted Jan. 16, 2016
}

function (Shoveller et al., 2005; Riedijk, et al., 2007; Chen et al., 2014; Shen et al., 2014).

Methionine is primarily produced by either chemical synthesis or hydrolyzing proteins. The product by chemical synthesis is DL-mixture of the amino acid (Mannsfeld et al., 1978; Gomes and Kumar, 2005) whereas hydrolysis of proteins leads to a complex mixture from which Met must be separated (Kumar and Gomes, 2005). It is commonly supplemented in diets as dry DL-methionine (DL-Met) or as liquid DL-Met hydroxy analog-free acid (MHA-FA). However, both the DL-Met and MHA-FA have to be converted to L-Met before it can be used by animals, and LMet is the only form used for protein synthesis and metabolism (Dibner and Ivey, 1992; Stoll et al., 1998; Martín-Venegas et al., 2006). The conversion of D-Met to L-Met is not a limiting factor due to the existence of substantial D-amino acid oxidase activity in different tissues, such as kidney, liver, stomach, duodenum, jejunum and ileum, of pigs (Fang et al., 2010). Recently a 
fermentation approach has been used to produce L-Met (Odunfa et al., 2001; Ikeda, 2003; Kumar and Gomes, 2005). During the fermentation process, L-Met precursor was obtained from microorganism strain, and mixed with converting enzyme and methyl mercaptan which converted the L-Met precursor to L-Met (Kim et al., 2015). Studies have been conducted on comparison on L-Met and DL-Met for pigs in the past (Cho et al., 1980; Kim and Bayley, 1983; Chung and Baker, 1992; Shen et al., 2014). Some of them were conducted more than 30 years ago. Shen et al. (2014) conducted two experiments to test the effect of dietary L-Met supplementation on growth performance and gut health in nursery pigs compared with DL-Met containing a basal diet $(0.18 \%$, standardized ileal digestibility [SID] Met) supplemented with L-Met or DLMet $0.048 \%, 0.096 \%$, and $0.144 \%$, respectively. However, little information is available on the effect of L-Met and DL-Met on nitrogen $(\mathrm{N})$ balance, and serum amino acid profile in starter pigs.

The objective of the present study was to determine the effect of L-Met as a Met source compared with DL-Met on $\mathrm{N}$ balance, serum protein, and amino acid profile in starter pigs.

\section{MATERIALS AND METHODS}

\section{General}

The experiment was conducted in the Metabolism Laboratory of Ministry of Agriculture Feed Industry Center (Beijing, China). The Institutional Animal Care and Use Committee at China Agricultural University (Beijing, China) reviewed and approved the protocols used in this study. L- and DL-methionine were obtained from CJ (CheilJedang Corporation, Seoul, Korea). L-methionine was produced by fermentation processes. The analyzed purity of L-Met and DL-Met was $99.3 \%$ and $99.2 \%$, respectively.

\section{Animals, diets, and experimental design}

Eighteen crossbred (Duroc $\times$ Landrace $\times$ Yorkshire) barrows with initial body weight of $15.45 \pm 0.88 \mathrm{~kg}$ were randomly allotted to 3 diets. The basal (BD) diet was formulated according to the recommendations of $\mathrm{NRC}$ (1998) with the exception of Met. The Met concentration in the basal diet was $0.24 \%$, which is below the Met requirement for piglets between 10 to $20 \mathrm{~kg}$ body weight according to NRC (1998). All other nutrients and energy were adequate for the basal diet. The other two experimental diets were formulated based on the basal diet, $0.12 \%$ either DL-Met or L-Met was supplemented. The SID value of Met in the experimental diets was $0.36 \%$, which met the recommendation of NRC (1998). The composition of all diets is presented in Table 1 . Before the beginning of
Table 1. Ingredients and nutrient contents of experimental diets (\%, as-fed basis)

\begin{tabular}{|c|c|c|c|}
\hline Items & Basal diet & L-Met & DL-Met \\
\hline \multicolumn{4}{|l|}{ Ingredients } \\
\hline Corn & 31.26 & 31.14 & 31.14 \\
\hline Wheat & 40.00 & 40.00 & 40.00 \\
\hline Soybean meal & 23.30 & 23.30 & 23.30 \\
\hline Soybean oil & 2.00 & 2.00 & 2.00 \\
\hline Dicalcium phosphate & 1.20 & 1.20 & 1.20 \\
\hline Limestone & 0.80 & 0.80 & 0.80 \\
\hline Sodium chloride & 0.30 & 0.30 & 0.30 \\
\hline Lysine & 0.48 & 0.48 & 0.48 \\
\hline Methionine & - & 0.12 & 0.12 \\
\hline Threonine & 0.16 & 0.16 & 0.16 \\
\hline Vit. Min. Mix ${ }^{1}$ & 0.50 & 0.50 & 0.50 \\
\hline Total & 100.00 & 100.00 & 100.00 \\
\hline \multicolumn{4}{|c|}{ Analyzed nutritional content } \\
\hline Crude protein & 18.94 & 18.55 & 18.52 \\
\hline Calcium & 0.70 & 0.71 & 0.70 \\
\hline Total phosphorous & 0.62 & 0.60 & 0.61 \\
\hline Lysine & 1.24 & 1.26 & 1.25 \\
\hline Methionine & 0.27 & 0.38 & 0.38 \\
\hline Methionine + cysteine & 0.60 & 0.72 & 0.74 \\
\hline \multicolumn{4}{|c|}{$\begin{array}{l}\text { L-Met, L-methionine; DL-Met, DL-methionine. } \\
\text { 'Provided per kilogram complete feed: vitamin A, } 12,000 \mathrm{IU} \text {; vitamin } \mathrm{D}_{5} \text {, } \\
\text { 2,500 IU; vitamin E } 30 \mathrm{IU} \text {; vitamin } \mathrm{K}_{3}, 3 \mathrm{mg} \text {; vitamin } \mathrm{B}_{12}, 0.012 \mathrm{mg} \text {; } \\
\text { vitamin } \mathrm{K}_{3}, 3 \mathrm{mg} \text {; riboflavin, } 4 \mathrm{mg} \text {; niacin, } 40 \mathrm{mg} \text {; pantothenic acid, } 15 \\
\text { mg; Choline chloride, } 400 \mathrm{mg} \text {; folic acid, } 0.7 \mathrm{mg} \text {; vitamin } \mathrm{B}_{1}, 1.5 \mathrm{mg} \text {; } \\
\text { vitamin } \mathrm{B}_{6}, 1.5 \mathrm{mg} \text {; Biotin, } 0.1 \mathrm{mg} \text {; } \mathrm{Zn}, 105 \mathrm{mg} \text {; Mn, } 22 \mathrm{mg} \text { Fe, } 84 \mathrm{mg} \text {; } \\
\mathrm{Cu}, 225 \mathrm{mg} \text {; I, } 0.50 \mathrm{mg} \text {; Se, } 0.35 \mathrm{mg} \text {. }\end{array}$} \\
\hline
\end{tabular}

experiment, the concentrations of AA in test diets were analyzed for confirmation. The pigs were individually housed in stainless-steel metabolism crates $(1.4 \times 0.7 \times 0.6 \mathrm{~m})$ and maintained in an environmentally controlled room with ambient temperature of $24 \pm 2^{\circ} \mathrm{C}$. All pigs were fed ad libitum and free access to water throughout the experiment.

\section{Management procedures}

The experiment lasted for 18 days, consisting of a 13day (d) adaptation period to the diets followed by a 5 -day (d) experimental period (total collection of feces and urine). Feed refusals and spillage were collected, dried, and weighed to correct feed intake. During the experimental period feed intake was recorded on daily basis.

\section{Sample collection}

Total feces and total urine were collected during the last $5 \mathrm{~d}$ of the study. During the 5 - $\mathrm{d}$ collection period, all feces were collected into plastic bags and stored at $-20^{\circ} \mathrm{C}$ immediately. At the end of the collection period, fecal samples from each pig were pooled and weighed and a 300 $\mathrm{g}$ sample was taken and dried in a forced-draft oven at $65^{\circ} \mathrm{C}$ for $72 \mathrm{~h}$. After drying and grinding, samples were stored at 
Table 2. Effect of different type of Met supplementation on $\mathrm{N}$ retention and excretion in pigs ${ }^{1}$

\begin{tabular}{|c|c|c|c|c|c|}
\hline Item & Basal diet & L-Met & DL-Met & SEM & p-value \\
\hline Initial BW (kg) & 15.43 & 15.47 & 15.45 & 0.38 & 0.99 \\
\hline Finial BW (kg) & 25.67 & 27.63 & 26.95 & 0.73 & 0.20 \\
\hline \multicolumn{6}{|l|}{ Nitrogen utilization } \\
\hline $\mathrm{N}$ intake $(\mathrm{g} / \mathrm{d})$ & $26.48^{\mathrm{b}}$ & $28.66^{\mathrm{a}}$ & $28.47^{\mathrm{a}}$ & 0.55 & 0.04 \\
\hline Fecal $N$ excreted (FN, g/d) & 5.76 & 4.90 & 5.04 & 0.49 & 0.47 \\
\hline Urine $N$ excreted (UN, g/d) & $8.34^{\mathrm{a}}$ & $5.33^{\mathrm{b}}$ & $5.37^{\mathrm{b}}$ & 0.50 & $<0.01$ \\
\hline Retained N (RN, g/d) & $12.38^{\mathrm{b}}$ & $18.43^{\mathrm{a}}$ & $18.06^{\mathrm{a}}$ & 0.77 & $<0.01$ \\
\hline $\mathrm{N}$ digestibility (\%) & 78.30 & 82.91 & 82.58 & 1.66 & 0.16 \\
\hline $\mathrm{N}$ retention rate $(\%)$ & $46.94^{\mathrm{b}}$ & $64.32^{\mathrm{a}}$ & $63.06^{\mathrm{a}}$ & 1.84 & $<0.01$ \\
\hline
\end{tabular}

L-Met, L-methionine; DL-Met, DL-methionine; SEM, standard error of the mean; BW, body weight.

${ }^{1}$ Data are means of 6 observations per treatment.

${ }^{a b}$ Means in a row followed by different letters are significantly different $(p<0.05)$.

$-20^{\circ} \mathrm{C}$ for further chemical analysis. Total urine samples were collected into plastic buckets attached to funnels located under the metabolism cages at the same time as the fecal collection. Approximately $50 \mathrm{~mL}$ of $6 \mathrm{~N} \mathrm{HCl}$ were added to each bucket to limit microbial growth and reduce loss of ammonia. Urine volume was recorded daily and a subsample of $10 \%$ of the urine excreted from each pig was collected and stored at $-20^{\circ} \mathrm{C}$. At the end of the collection period, urine samples were pooled for each pig and a subsample was prepared for further analysis.

On the second day after the collection period, blood samples were collected from the precava of each pig into 10 $\mathrm{mL}$ heparin-free tubes (Greiner Bio-One Company, Monroe, $\mathrm{NC}, \mathrm{USA})$ at $0800 \mathrm{~h}$. Blood samples were then centrifuged $\left(3,000 \times g\right.$ at $4^{\circ} \mathrm{C}$ for $\left.15 \mathrm{~min}\right)$ within $1 \mathrm{~h}$ of collection, and serum samples were stored at $-20^{\circ} \mathrm{C}$ until ready for serum urea nitrogen (SUN) and AA analysis.

\section{Chemical analysis}

Dry matter (method 934.01), crude protein (method 990.03), ash (method 942.05), and $\mathrm{Ca}$ and $\mathrm{P}$ (method 985.01) content of the diets were analyzed according to the procedures of the AOAC International (2007).

Amino acids in diets were analyzed according to the AOAC International (2007; method 151 982.30). Samples were hydrolyzed with $6 \mathrm{~N} \mathrm{HCl}$ at $110^{\circ} \mathrm{C}$ for $24 \mathrm{~h}$ and analyzed for lysine using an Amino Acid Analyzer (Hitachi L-8900, Tokyo, Japan). Methionine and cysteine were determined as methionine sulfone and cysteic acid after oxidized with cold performic acid overnight and hydrolyzed with $7.5 \mathrm{~N} \mathrm{HCl}$ at $110^{\circ} \mathrm{C}$ for $24 \mathrm{~h}$. An Amino Acid Analyzer (Hitachi L-8900, Tokyo, Japan) was used for the measurements.

Blood urea nitrogen, total protein (TP), albumin (ALB), and glucose concentrations were measured using an Automatic Biochemistry Analyzer (Hitachi 7020, Japan). Serum AA concentrations were determined by ion-exchange chromatography with physiological fluid analysis conditions (S-433D AA Analyzer, Sykam, Germany) according to Zhang et al. (2013). Frozen serum samples were first thawed at $4{ }^{\circ} \mathrm{C}$ and then deproteinized with 120 $\mathrm{mg}$ of salicylic acid/mL of serum. After samples were placed an ice bath for $20 \mathrm{~min}$, the reaction system was adjusted for $\mathrm{pH}$ by adding lithium hydroxide solution (2 $\mathrm{mol} / \mathrm{L}$ ) and then centrifuged at $12,000 \mathrm{~g}$ (L-80 XP, Beckman, Brea, CA, USA) for $30 \mathrm{~min}$. The supernatant fluid was collected and then passed through a filter $(0.1 \mu \mathrm{m})$ before use for AA analysis.

\section{Statistical analysis}

Data were analyzed using the general linear model procedure of SAS (SAS Inst. Inc., Cary, NC, USA) followed by Student-Newman-Keuls multiple tests. In all analyses, the differences were considered to be significant if $\mathrm{p}<0.05$.

\section{RESULTS}

\section{Nitrogen-balance}

Supplementation of either L-Met or DL-Met improved $\mathrm{N}$ retention $(\mathrm{p}<0.01)$ and $\mathrm{N}$ retention rate $(\mathrm{p}<0.01)$ when compared with the BD (Table 2). No difference was found in $\mathrm{N}$ retention and $\mathrm{N}$ retention rate between the DL-Met and L-Met treatments.

Supplementation of either L-Met or DL-Met significantly decreased $(\mathrm{p}<0.01)$ urine nitrogen when compared with the $\mathrm{BD}$ group. No difference in total $\mathrm{N}$ excretion was observed between the DL-Met treatment and the L-Met treatment $(\mathrm{p}>0.05)$.

\section{Serum amino acid profile and metabolites}

The serum amino acid profile of pigs fed the different diets is presented in Table 3. Compared with the BD group, supplementation of either L-Met or DL-Met increased $(p<0.01)$ the serum Met concentration. Supplementation of L-Met significantly decreased $(p<0.05)$ serum glycine 
Table 3. Effect of different type of Met supplementation on serum amino acids concentrations in pigs ${ }^{1}$

\begin{tabular}{|c|c|c|c|c|c|}
\hline Serum amino acids (nmol/mL) & Basal diet & L-Met & DL-Met & SEM & $\mathrm{p}$-value \\
\hline \multicolumn{6}{|l|}{ Indispensable amino acid } \\
\hline Lysine & 297.72 & 260.35 & 272.11 & 5.89 & 0.14 \\
\hline Threonine & 446.01 & 442.19 & 443.30 & 9.26 & 0.96 \\
\hline Methionine & $33.04^{\mathrm{b}}$ & $50.70^{\mathrm{a}}$ & $53.18^{\mathrm{a}}$ & 0.83 & $<0.01$ \\
\hline Arginine & 145.65 & 139.91 & 157.05 & 5.77 & 0.14 \\
\hline Histidine & 86.75 & 85.27 & 80.51 & 3.00 & 0.33 \\
\hline Leucine & 243.45 & 214.21 & 229.07 & 9.26 & 0.17 \\
\hline Isoleucine & 137.01 & 123.62 & 116.74 & 6.80 & 0.13 \\
\hline Phenylalanine & 97.18 & 110.68 & 113.71 & 5.51 & 0.11 \\
\hline Tryptophan & 66.91 & 70.06 & 70.59 & 3.10 & 0.67 \\
\hline Valine & 205.47 & 179.45 & 186.84 & 11.23 & 0.27 \\
\hline \multicolumn{6}{|l|}{ Dispensable amino acid } \\
\hline Cysteine & 17.54 & 18.36 & 19.52 & 0.72 & 0.18 \\
\hline Aspartic acid & 153.50 & 140.82 & 146.19 & 8.54 & 0.58 \\
\hline Glutamic acid & 228.89 & 201.58 & 193.79 & 11.97 & 0.13 \\
\hline Alanine & 656.74 & 580.52 & 607.85 & 26.25 & 0.15 \\
\hline Glycine & $1,362.67^{\mathrm{a}}$ & $1,186.71^{b}$ & $1,277.71^{\mathrm{ab}}$ & 37.63 & 0.02 \\
\hline Serine & 195.68 & 167.36 & 180.45 & 10.07 & 0.17 \\
\hline Tyrosine & 115.76 & 131.24 & 125.92 & 5.72 & 0.18 \\
\hline
\end{tabular}

L-Met, L-methionine; DL-Met, DL-methionine; SEM, standard error of the mean.

${ }^{1}$ Data are means of 6 observations per treatment.

${ }^{a b}$ Means in a row followed by different letters are significantly different $(p<0.05)$.

concentration when compared with the BD control. There were no differences in most serum AA concentrations and in treatments.

The results of SUN, serum ALB, and TP concentration are shown in Table 4. Supplementation of either L-Met or DL-Met increased TP concentration and decreased SUN concentration when compared with the BD group $(\mathrm{p}<0.01)$ without differences between the DL-Met treatment and the L-Met treatment.

\section{DISCUSSION}

Studies have been conducted to evaluate the effects of supplementing of different sources of Met in monogastric feed since 1980. The results of those studies were not consistent. Kim and Bayley (1983) has used the oxidation of phenylalanine as an indicator to determine the

Table 4. Effect of different type of Met supplementation on serum urea nitrogen (SUN), albumin, and total protein concentration in pigs $^{1}$

\begin{tabular}{lccccc}
\hline Item & Basal diet & L-Met & DL-Met & SEM & p-value \\
\hline Albumin $(\mathrm{g} / \mathrm{L})$ & 37.58 & 39.27 & 39.04 & 0.71 & 0.22 \\
Total protein $(\mathrm{g} / \mathrm{L})$ & $58.22^{\mathrm{b}}$ & $70.30^{\mathrm{a}}$ & $69.83^{\mathrm{a}}$ & 1.62 & $<0.01$ \\
SUN $(\mathrm{mmoL} / \mathrm{L})$ & $5.10^{\mathrm{a}}$ & $3.90^{\mathrm{b}}$ & $3.97^{\mathrm{b}}$ & 0.18 & $<0.01$ \\
\hline
\end{tabular}

L-Met, L-methionine; DL-Met, DL-methionine; SEM, standard error of the mean.

${ }^{1}$ Data are means of 6 observations per treatment.

${ }^{a b}$ Means in a row followed by different letters are significantly different $(\mathrm{p}<0.05)$. requirement of Met and the efficacy of L-Met compared with D-Met. The results indicated that D-Met was 50\% efficacious relative to L-Met in young pigs. In contrast, it was also reported that L-Met and DL-Met has the same efficacy on growth performance in pigs (Chung and Baker, 1992) and in chicks (Garlich, 1985; Dilger and Baker, 2007), or even L-Met was found to have less efficacy than D-Met and DL-Met in chicks (Tipton et al., 1966). Some studies found that efficacy of Met utilization is different with supplementation of dietary Met levels and whether Met was added as the sole source sulfur amino acid. For example, Katz and Baker (1975) conducted four experiments to evaluate the relative efficacy of different sources of Met and to estimate the requirement for D- and L-Met of broiler chickens when was Met serving as the sole source of sulfur AA or when added to a diet containing $0.27 \%$ L-cystine. Their results showed that at lower levels of supplementation, L-Met is a better source of sulfur AA than D-Met on growth performance of broiler chickens. L- and D-Met have equal efficacy when incorporated into diets that are only marginally deficient in sulfur-containing AA.

Our data provided evidence to support earlier results indicating that the efficacy of L-Met and DL-Met is indistinguishable (Cho et al., 1980; Chung and Baker, 1992). However, Shen et al. (2014) reported that the relative bioavailability (RBA) of L-Met to DL-Met in nursery pigs for average daily gain (ADG) and gain:feed ratio was $143.8 \%$ and $122.7 \%$, respectively. The inconsistency in 
different reports is likely due to many factors. Some studies pointed out that the body weight of animals could lead to the difference of results (Chung and Baker, 1992; Shen et al., 2014). Moreover, at lower levels of Met supplementation below the requirement supplementation as the sole source of sulfur AA or the difference of relative contribution of Met and cysteine to treatment diet may also cause discrepancy (Katz and Baker, 1975; Christensen et al., 1980). Ball et al. (2006) reported that more than $40 \%$ of the sulfur amino acid requirement can be met by dietary cysteine. Cysteine has the sparing effect on Met requirement which may alleviate the deficiency of Met (Shoveller et al., 2003).

Nitrogen retention or $\mathrm{N}$ balance reflects the utilization of proteins, the balance between the body protein synthesis and body protein degradation (Metayer et al., 2008). In the current study, when compared with $\mathrm{BD}$ group, both L-Met and DL-Met diets improved retained $\mathrm{N}(\mathrm{p}<0.01)$ and $\mathrm{N}$ retention rate $(\mathrm{p}<0.01)$ demonstrating a better utilization of nitrogen in L-Met and DL-Met treatments than the control. There was no difference in $\mathrm{N}$ retention and $\mathrm{N}$ retention rate between the DL-Met and L-Met treatments. In contrast, Shen et al. (2014) reported that the RBA of L-Met to DLMet estimated from concentrations of plasma urea nitrogen on d 10 was $160.2 \%$. However, on d 20 no difference in ADG was observed between the L-Met and DL-Met treatments which indicated that utilization of Met isomers may be a function of age. The initial body weight of pigs in their study was $7.15 \pm 0.97 \mathrm{~kg}$ (weanling pigs). In our study it was $15.45 \pm 0.88 \mathrm{~kg}$. This may partly explain the inconsistency between the results presented by Shen et al. (2014), and those showed in this study.

The estimation of plasma urea nitrogen is a rapid method to estimate amino acid requirement in pigs (Coma et al., 1995). A rapid response in nitrogen metabolism was found when there was a change in the concentration of dietary AA. The reduction of plasma urea nitrogen reflects more efficient nitrogen utilization and, consequently, decreased the urea synthesis (Brown and Cline, 1974). In present study, the low level of SUN in Met supplemented group reflects a low level of urea synthesis and a higher efficiency of AA or nitrogen utilization. To our knowledge, D-Met must be converted to L-Met before it can be used by the gastrointestinal tract (Dibner and Ivey, 1992). The ratelimiting enzyme for conversion of D-Met to L-Met is D-AA oxidase (Fang et al., 2010). The existence of substantial DAA oxidase activity in different tissues, not only liver and kidney (major sites conversion) but also the gastrointestinal tract (stomach, duodenum, jejunum and ileum) can efficiently convert D-Met to L-Met in pigs (Fang et al., 2010). Thus, the effective conversion of D-Met to L-Met might possibly explain the result that the supplementation of L-Met did not affect SUN and serum amino acid profile compared with DL-Met treatment.

Although this absorption and metabolism of Met from different sources were not evaluated in this study, it is necessary to conduct more experiments to investigate the metabolism of amino acid utilization.

\section{CONCLUSION}

In present study, the results indicated that supplementation of either L-Met or DL-Met improved $\mathrm{N}$ retention, and decreased $\mathrm{N}$ excretion. The $\mathrm{N}$ retention of pigs fed diets supplemented with the same inclusion levels of DL-Met or L-Met were not different indicating that DLMet and L-Met are equally bioavailable as Met sources for starter pigs.

\section{CONFLICT OF INTEREST}

We certify that there is no conflict of interest with any financial organization regarding the material discussed in the manuscript.

\section{ACKNOWLEDGMENTS}

The study was financially supported by the National Natural Science Foundation of China (No. 31372316) and CJ Corporation, Seoul, Korea.

\section{REFERENCES}

AOAC. 2007. Official Methods of Analysis. 18th ed. Association of Official Analytical Chemists, Arlington VA, USA.

Ball, R. O., G. Courtney-Martin, and P. B. Pencharz. 2006. The in vivo sparing of methionine by cysteine in sulfur amino acid requirements in animal models and adult humans. J. Nutr. 136:1682S-1693S.

Brown, J. A. and T. R. Cline. 1974. Urea excretion in the pig: an indicator of protein quality and amino acid requirements. J. Nutr. 104:542-545.

Chen, Y., D. Li, Z. Dai, X. Piao, Z. Wu, B. Wang, Y. Zhu, and Z. Zeng. 2014. L-Methionine supplementation maintains the integrity and barrier function of the small-intestinal mucosa in post-weaning piglets. Amino Acids 46:1131-1142.

Cho, E. S., D. W. Andersen, L. J. Filer, and L. D. Stegink. 1980. D-methionine utilization in young miniature pigs, adult rabbits, and adult dogs. J. Parenter. Enteral. Nutr. 4:544-547.

Christensen, A. C., J. O. Anderson, and D. C. Dobson, 1980. Factors affecting efficacy of methionine hydroxy analogue for chicks fed amino acid diets. Poult. Sci. 59:2480-2484.

Chung, T. K. and D. H. Baker. 1992. Utilization of methionine isomers and analogs by the pig. Can. J. Anim. Sci. 72:185-188.

Coma, J., D. Carrion, and D. R. Zimmerman. 1995. Use of plasma urea nitrogen as a rapid response criterion to determine the lysine requirement of pigs. J. Anim. Sci. 73:472-481.

Cromwell, G. L. 2004. Identifying the limiting amino acids in complex and cereal grain-based diets to minimize nitrogen 
excretion. In Midwest Swine Nutr. Conf. Proc. Indianapolis, IN, USA. The Ohio Univ. Press, Columbus, OH, USA. pp. 6983.

Dibner, J. J. and F. J. Ivey. 1992. Capacity in the liver of the broiler chick for conversion of supplemental methionine activity to L-methionine. Poult. Sci. 71:700-708.

Dilger, R. N. and D. H. Baker. 2007. DL-Methionine is as efficacious as L-methionine, but modest L-cystine excesses are anorexigenic in sulfur amino acid-deficient purified and practical-type diets fed to chicks. Poult. Sci. 86:2367-2374.

Fang, Z., H. Luo, H. Wei, F. Huang, Z. Qi, S. Jiang, and J. Peng. 2010. Methionine metabolism in piglets fed DL-methionine or its hydroxy analogue was affected by distribution of enzymes oxidizing these sources to keto-methionine. J. Agric. Food Chem. 58:2008-2014.

Finkelstein, J. D. 1990. Methionine metabolism in mammals. J. Nutr. Biochem. 1:228-237.

Gomes, J. and D. Kumar. 2005. Production of L-methionine by submerged fermentation: A review. Enzyme Microb. Tech. 37:3-18.

Garlich, J. D. 1985. Response of broilers to DL-methionine hydroxy analog free acid, DL-methionine, and L-methionine. Poult. Sci. 64:1541-1548.

Ikeda, M. 2003. Amino acid production processes. In: Microbial Production of L-amino Acids. Springer Berlin Heidelberg, Germany. pp. 1-35.

Katz, R. S. and D. H. Baker. 1975. Efficacy of D-, L- and DLmethionine for growth of chicks fed crystalline amino acid diets. Poult. Sci. 54:1667-1674.

Kim, K. I. and H. S. Bayley. 1983. Amino acid oxidation by young pigs receiving diets with varying levels of sulphur amino acids. Br. J. Nutr. 50:383-390.

Kim, S. Y., K. M. Cho, Y. U. Shin, H. W. Um, K. O. Choi, J. S. Chang, Y. W. Cho, and Y. H. Park. 2015. Microorganism producing L-methionine precursor and method of producing Lmethionine and organic acid from the L-methionine precursor. US Patent 9029105.

Kumar, D. and J. Gomes. 2005. Methionine production by fermentation. Biotechnol. Adv. 23:41-61.

Mannsfeld, S. P., A. Pfeiffer, H. Tanner, H. Wagner, and E. Liebertanz. 1978. Continuous process for the manufacture of methionine. US Patent 04069251.
Martín-Venegas, R., P. A. Geraert, and R. Ferrer. 2006. Conversion of the methionine hydroxy analogue DL-2-hydroxy-(4methylthio) butanoic acid to sulfur-containing amino acids in the chicken small intestine. Poult. Sci. 85:1932-1938.

Metayer, S., I. Seiliez, A. Collin, S. Duchene, Y. Mercier, P. A. Geraert, and S. Tesseraud. 2008. Mechanisms through which sulfur amino acids control protein metabolism and oxidative status. J. Nutr. Biochem. 19:207-215.

NRC. 1998. Nutrient Requirements of Swine, 10th edition. National Academic Press, Washington, DC, USA.

Odunfa, S. A., S. A. Adeniran, O. D. Teniola, and J. Nordstrom. 2001. Evaluation of lysine and methionine production in some lactobacilli and yeasts from Ogi. Int. J. Food Microbiol. 63:159-163.

Riedijk, M. A., B. Stoll, S. Chacko, H. Schierbeek, A. L. Sunehag, J. B. van Goudoever, and D. G. Burrin. 2007. Methionine transmethylation and transsulfuration in the piglet gastrointestinal tract. Proc. Natl. Acad. Sci. USA. 104:34083413.

Shen, Y. B., A. C. Weaver, and S. W. Kim. 2014. Effect of feed grade L-methionine on growth performance and gut health in nursery pigs compared with conventional DL-methionine. J. Anim. Sci. 92:5530-5539.

Shoveller, A. K., J. A. Brunton, J. D. House, P. B. Pencharz, and R. O. Ball. 2003. Dietary cysteine reduces the methionine requirement by an equal proportion in both parenterally and enterally fed piglets. J. Nutr. 133:4215-4224.

Shoveller, A. K., B. Stoll, R. O. Ball, and D. G. Burrin. 2005. Nutritional and functional importance of intestinal sulfur amino acid metabolism. J. Nutr. 135:1609-1612.

Stoll, B., J. Henry, P. J. Reeds, H. Yu, F. Jahoor, and D. G. Burrin. 1998. Catabolism dominates the first-pass intestinal metabolism of dietary essential amino acids in milk protein-fed piglets. J. Nutr. 128:606-614.

Tipton, H. C., B. C. Dilworth, and E. J. Day. 1966. A comparison of D-, L-, DL-methionine and methionine hydroxy analogue calcium in chick diets. Poult. Sci. 45:381-387.

Zhang, S., S. Qiao, M. Ren, X. Zeng, X. Ma, Z. Wu, P. Thacker, and G. Wu. 2013. Supplementation with branched-chain amino acids to a low-protein diet regulates intestinal expression of amino acid and peptide transporters in weanling pigs. Amino Acids 45:1191-1205. 